\title{
Incivility? It's Effect On Performance In Organization
}

\author{
Nigarish \\ University of Management and Technology Lahore \\ Uswa \\ University of Management and Technology Lahore \\ Bakhtawar Islam \\ University of Management and Technology Lahore \\ Sajid Ali \\ University of Management and Technology Lahore
}

\begin{abstract}
This article is review study about the incivility in this we talk and read the authors Previous studies and take help to understand the incivility? Its causes and its effects On performance of employees. How its make negative influence in organization. There is different kinds of incivility like rude comments, insensitive actions, Crude jokes, unintentional slights, gossiping etc. The employees how to react when They face this kind of behaviour and also incivility is the reason of absenteeism and Negative influence on commitment how to the high management promote civility. So the employees work with fresh minds. Sometime incivility occur in organization But not recognize it, but some understand the harmful effect of it .In some Organization the manger also Deal with it.
\end{abstract}

Keywords; incivility, performance, workplace, employees, organization, productive, behaviour, problem.

\section{INTRODUCTION}

Workplace incivility is any negative behaviour that demonstrates a lack of regard for other workers. The incivility is a vast number of negative behaviours and disrespectful behaviours negative like gossiping rude comments, crude jokes, and unintentional slights insensitive actions. There is two types of incivility one is Verbal aggression and second is physical aggression.in verbal aggression include cursing at others ,humiliation on others and threats in physical or sexual aggression include harassment, assault, battery and inappropriate touching. This type of behaviour make employees uncomfortable and mentally stressed-out.so they not give there $100 \%$ to their work which also is a reason to decrease the productive of organization and organization have their first preference is profit if the employees not mentally relax they are not productive for organization. The Andersson \& Pearson said in 1999 that "Workplace incivility refers to unacceptable behaviour workplace principle". Milam, Spitzmueller, and Penney, 2009; Pearson and Porath, 2002 said that the incivility is usual in workplace. According to Griffin, 2010 workplace incivility has linkage with intention to quit when employees ignore this kind of behave then who are behave uncivil our quietness give then more strengthen. Lim, Cortina, \& Magley, 2008; Lim \& Lee, 2011 link its with employees satisfaction .in 2008 Lim et al link incivility effects mental and physical health. Lim \& Lee, 2011 said work family conflict and clegg 1983 link it's with absenteeism. When employees are not mentally satiable they do not work effectively in any organization now organization suffering 
some problems like lower moral of workers, decrease in employees ,increase in absenteeism of employees and low commitment towards the organizational. psychological distress is connected with incivility .

Incivility is conceptualize as social phenomenon, Andersson and Pearson (1999) described it as an escalating exchange of behaviours between colleagues.

More than A \$6billion yearly in Australian industry money related effect on associations related with work environment incivility (Hanley and O'Rourke 2016).According to (Andersson and Pearson 1999; Cortina et al. 2001).workplace incivility is disrespectful, discourteous low intensity mistreatment, rudeness.

Employees engagement to an organization is affected widely some factors like rewards, quality of life, career development, career opportunities, company practice said Bennett \& Bell, 2004.When people are treated with dignity, respect and with good behaviour will affect their commitment to stick with the organization speak positively about it, and work hard to contribute to its success.

Uncivil behaviours at organization make employee's confidence down so they not contribute in innovation, novel ideas and solution for example introduce the new ideas in systematic way, search new working method, instruments or techniques, and also generate the solutions of problems

Also according to AET, worker who face uncivility at work are not willing to elaborate ideas or thoughts or solutions to complex problems and that's why drive innovation block (Grant and Berry 2011).

"Zhang et al. (2014) placed that representatives' view of injurious supervision add to a decrease in inventiveness by means of stifled inherent inspiration."

What is incivility in work place? How much it has vast meaning. How incivility effects on organization .how effect the performance in workplace. Carpini, Parker and Griffin 2017 said in-role job performance is based on activities related to formal tasks, responsibilities and duty require by job. Incivility is not one ward it has many kinds relate to person, situation and environment for all people incivility is not same it depend what kind of behave they faced. Representatives' in job work execution can be influenced by the hindering impacts of work environment incivility in a few different ways (Pearson and Porath 2005).

In the main laborer who face or experience working environment uncivil carry on they may neglect to finish all duties required by their activity. Because the employees are mentally stressed out they do mistake in work and forget thing unintentionally. AET proposes that uncivil medications in the work environment will cause abstract passionate responses in representatives and instigate decrease in subjective working (Griffin and Clark 2014; Sakurai and Jex 2012).

There must be some cures to fight the incivility in work place. We also try to find out some. If there is some law and regulations in organization there must be mark difference. The upper management also some time include in uncivil acts which make people more negative. We get all secondary data which help us to make more clear thing about it. 


\section{PURPOSE OF THE STUDY}

The purpose of our study to know about what is work place incivility. Its effect on organization performance and also its moderating effect like organization commitments and its types. How we come over the incivility negative effects and make environment positive and productive. For it we take help form previous working of other author on incivility.

\section{LITRATURE REVIEW}

This investigation expands the writing on relational disregard in the working environment by grabbing of representatives and effect of incivility for example rudeness, disrespectful behave .psychological distress is the reason which is connect directly to uncivil workplace experiences. The author discuss their findings about incivility how it effect performance, employee's motivation towards their work, loss in production .these things that all make negative impact on organization and our purpose of study is that how we come over its bad effects. This research examine response of worker in result of incivility and how this result associated with absenteeism and organization commitment

Our domino impact underline the requirement for associations to oversee thoughtfulness so they and their representatives can avoid impressive immediate and aberrant costs associated with work environment incivility Incivility "implies rudeness and disregard for others in a manner that violates norms for respect" ( Porath \& Pearson, 2004).according to (Terlecki, 2011) social maintain, ecological risk included in work characteristics and the individual characteristics such as negative affectivity are the important experience of the workplace incivility.

\section{INCIVILITY CAUSES}

Absence of poise Incivility, in any unique circumstance, can be effectively maintained a strategic distance from and furthermore controlled, if people will effectively rehearse patience one can safe his self from it.

Namelessness .Studies have demonstrated that individuals are imprudent when they realize that they can't be made responsible for their activities

Stress. Also incivility traced out because of personal and work-related stress.

More over environmental factor like lack of trust among workers, salary issues are also causes of incivility.

Our article is reviewed article we are talking about what constitute incivility in a workplace? Sometime old employees cannot expect the new one. They not adjust each other in their work. Environmental factor such as less loyalty to the company, no trust among the employees, short-term profitability, salary conflicts, informal culture in the office, this thing make uncivil behave in organization. The major aspect that we talk about which are result of incivility is absenteeism, commitment, and performance. When the employees face in civil behave in their workplace they are not able to perform their best as they can do. The expense of incivility that need to manage the association. Insolent and uncivil practices less efficiency and contrarily impact staff fulfilment. Staff wiped out leave use, less of efficiency, staff turnover, staff withdrawal.

\section{Employee Absenteeism}

As per the (EES, 2011) brought about a large number of long stretches of wiped out leave use that cost the association a great many dollars. These suggestions were attached to their 
business results - explicitly; work nearness and work quality. At the point when participation is low, authoritative efficiency endures. Hence, every result was inspected against work environment incivility. To begin with, every wa characterized: Absenteeism - "Interminable nonappearance (as from work or school), or something" ("Absent," 2013, para 3); and, execution. "The demonstration, or procedure of performing towards achievement" ("Performance," 2013,para. 7). For example, on the off chance that associations were focused on hierarchical equity, at that point representatives would act better and show execution results (quality profitability) to lessen authoritative expenses.

\section{Organization Commitment}

Incivility has negative effect on people behaves when they make their opinion negative about company and its people this thing effect commitment. This is very important issue.

Employees who committed with their organization if they leave job so that is big loss of organization.

Commitment has positive correlation with attendance and highly negative correlated with absenteeism.

- There is there types of organizational commitment

- one is affective commitment; Full of feeling duty identifies with how much workers need to remain at their association.

- Second is continuous commitment; Continuation responsibility identifies with how much representatives want to remain at their association.

- Third is normative commitment Regulating responsibility identifies with how much workers feel they should remain at their association.

Incivility is never again a matter of basically not playing reasonable in America's or play areas, nor is it contained there. Work environment uncivil practices have filled a horde of talks. Incivility/disregard is dynamic in open working environments, explicitly, If representatives are uncivil, authoritative objectives may endure because of worker non-appearance and poor execution. A few impacts of office wrongdoing toward representatives' unscheduled nonappearance and/or work quality incorporated into this part is an authentic foundation of work environment incivility in Organization and that identifies with the examination' issue and reason. It explained a few points of view of what incivility (affront) implied: impoliteness, evasion, prohibition, rejecting, overlooking, and injustice 


\section{THEORETICAL FRAMEWORK}

Figure

\section{Organization Commitment}

(Independent variable)

\section{Workplace Incivility}

(Moderating variable)

(Dependent variables)

Employee Absenteeism

\section{Explanation}

In this theoretical framework show three variables independent variable is Workplace Incivility, dependent variable is Employees absenteeism and moderating variable is Organization Commitment .Because of incivility absenteeism is increase in an organization its effect is negative on organization. The moderating variable organization commitment found some time positive correlation with attendance and also found some time and on some places negative correlation with absenteeism it also depend on type of organization commitment.

\section{Recommendations}

This is very important to reduce the work stress from employees. Uncivil behave is the reason of losses organization commitment and increase in absenteeism. This is highly recommended that to management of organization to examine the sector or its unit's absenteeism report if it is not up to the mark so conduct the analysis. Provide training programs for new hired workers give them basic information of how communicate in your organization, rule and regulation and also norms of your organization.

\section{Ramification of the Study}

Higher management could deal with the negative effect of incivility in the way to make understandable policies and procedure, information infrastructure, effective communication plans, response and direction, to come-over from the incivility bed effects on employees. The mangers can re-examine the hiring and make different criteria to check the personality characteristic. And find errors this kind of research is give advantages to personal management .Absenteeism is the issue which is result of incivility at workplace so to control it there must be plan or policies which communicated to employees. When there is check and balance so chance of incivility are also decrease in organization.

\section{How to promote High management to civility in there organization?}

Civility basically is respectful behave. And incivility is its contrast .although research of an organization about incivility is still preliminary stage because of its roots in interpersonal conflicts.

Manger have the main part to make civil behaviour in organization so for it he examine his selffirst that how he take part in civility. When management treat each other or employees respectfully they also do the same. And also when management respect their dignity.When the 
management make rule so they have to stick with them in any situation make check and balance on every unit of staff how they treat each other.

The manger have to encourage the practice of forgiveness. Not listen the rumours and gossip. Make solution to problems .deal with conflict on common ground. Stop to blame game. Make a special effort to state thank you and advance great conduct in staff.

\section{CONCLUSION}

The exploration look at association among incivility and representative truancy and impact of responsibility was likewise analysed on it. relationship between absenteeism and incivility is positive and the relationship between commitment and incivility is negative one person who cure it is manger. If we not take any action against incivility we have face crisis like less productivity, staff turnover etc.

\section{References}

Andersson, L. M., \& Pearson, C. M. (1999). Tit for tat? The spiraling effect of incivility in the workplace. academy of management review,24(3),452-471

Milam, A. C., Spitzmueller, C., \& Penney, L. M. (2009). Investigating individual differences among Targets of workplace incivility .journal of occupational health psychology,14(1),58

Griffin, B. (2010). Multilevel relationships between organizational-level incivility, justice and intention to Stay.Work \& stress,24(4),309-323.

Lim, S., \& Lee, A. (2011). Work and nonwork outcomes of workplace incivility: Does family support help? Journal of Occupational Health Psychology,16(1),95.

Lim, S., Cortina, L. M., \& Magley, V. J. (2008). Personal and workgroup incivility: impact on work and health outcomes. Journal of Applied Psychology, 93(1), 95.

Andersson, L. M., \& Pearson, C. M. (1999). Tit for tat? The spiraling effect of incivility in the workplace Academy of management review, 24(3), 452-471.

Pearson, C. M., Andersson, L. M., \& Wegner, J. W. (2001). When workers flout convention: A study of workplace incivility. Human Relations, 54(11), 1387-1419

Zhang H, HK Kwan, X Zhang and LZ Wu (2014) High core self-evaluators maintain creativity: a motivational model of abusive supervision. Journal of Management 40(4), 1151-1174.

Carpini JA, SK Parker and MA Griffin (2017) A look back and a leap forward: a review and synthe of the individual work performance literature. Academy of Management Annals 11(2), 825- 885.

Sakurai K and SM Jex (2012) Coworker incivility and incivility targets' work effort and counterproductive work behaviors: the moderating role of supervisor social support. Journal of Occupational Health Psychology 17(2), 150-161.

Jackson, S. E., \& Maslach, C. (1982). After-effects of job-related stress: Families as victims. Journal of organizational behavior, 3(1), 63-77.

Steers, R. M., \& Rhodes, S. R. (1978). Major influences on employee attendance: A process model. Journal of Applied psychology, 63(4), 391.

Hackett, R. D., Bycio, P., \& Hausdorf, P. A. (1994). Further assessments of Meyer and Allen's (1991) threecomponent model of organizational commitment. Journal of applied psychology, 79(1), 15-23.

Somers, M. J. (1995). Organizational commitment, turnover and absenteeism: An examination of direct and interaction effects. Journal of organizational Behavior, 16(1), 49-58. 